\title{
The Economic Consequences of IFRS: The Impact of IAS 32 on Preference Shares in the Netherlands
}

\author{
Abe de Jong, Miguel Rosellón and Patrick Verwijmeren
}

\begin{tabular}{|l|l|}
\hline \multicolumn{2}{|l|}{ ERIM REPORT SERIES RESEARCH IN MANAGEMENT } \\
\hline ERIM Report Series reference number & ERS-2006-021-F\&A \\
\hline Publication & May 2006 \\
\hline Number of pages & 24 \\
\hline Persistent paper URL & \\
\hline Email address corresponding author & pverwijmeren@rsm.nl \\
\hline Address & Erasmus Research Institute of Management (ERIM) \\
& RSM Erasmus University / Erasmus School of Economics \\
& Erasmus Universiteit Rotterdam \\
& P.O.Box 1738 \\
& 3000 DR Rotterdam, The Netherlands \\
& Phone: $\quad+31104081182$ \\
& Fax: $\quad+31104089640$ \\
& Email: info@erim.eur.nl \\
& Internet: $\quad$ www.erim.eur.nl \\
\hline
\end{tabular}

Bibliographic data and classifications of all the ERIM reports are also available on the ERIM website: www.erim.eur.nl 


\section{ERASMUS RESEARCH INSTITUTE OF MANAGEMENT}

\section{REPORT SERIES \\ RESEARCH IN MANAGEMENT}

\begin{tabular}{|l|l|}
\hline ABSTRACT AND KEYWORDS \\
\hline Abstract & $\begin{array}{l}\text { The consequences of international accounting standards are likely to reach beyond the impact } \\
\text { on financial statements. This paper demonstrates one of the economic implications of } \\
\text { international standards. We focus on the impact of the IFRS regulation on preference shares } \\
\text { (IAS 32) in the Netherlands. IAS 32 causes most preference shares to lose their classification as } \\
\text { equity and these shares will hence be classified as liabilities. We document that for Dutch firms } \\
\text { with preferred stock outstanding, the reclassification will on average increase the reported debt } \\
\text { ratio by 35\%. We find that 71\% of the firms that are affected by IAS 32 buy back their preference } \\
\text { shares or alter the specifications of the preference shares in such a way that the classification as } \\
\text { equity can be maintained. The main determinant of the decision whether to give these } \\
\text { consequences to IAS 32 is the magnitude of the impact of IAS 32 on a firm's debt ratio. We } \\
\text { conclude that IFRS does not only lead to a decrease in the use of financial instruments that } \\
\text { otherwise would have added to the capital structure diversity, but also changes firms' real capital } \\
\text { structure. }\end{array}$ \\
\hline Free Keywords & $\begin{array}{l}\text { Economic Consequences, Accounting Changes, IFRS, IAS 32, Preference Shares, Magnitude } \\
\text { Effect }\end{array}$ \\
\hline Availability & $\begin{array}{l}\text { The ERIM Report Series is distributed through the following platforms: } \\
\text { Academic Repository at Erasmus University (DEAR), DEAR ERIM Series Portal } \\
\text { Social Science Research Network (SSRN), SSRN ERIM Series Webpage } \\
\text { Research Papers in Economics (REPEC), REPEC ERIM Series Webpage }\end{array}$ \\
\hline Classifications & $\begin{array}{l}\text { The electronic versions of the papers in the ERIM report Series contain bibliographic metadata } \\
\text { by the following classification systems: } \\
\text { Library of Congress Classification, (LCC) LCC Webpage } \\
\text { Journal of Economic Literature, (JEL), JEL Webpage } \\
\text { ACM Computing Classification System CCS Webpage } \\
\text { Inspec Classification scheme (ICS), ICS Webpage }\end{array}$ \\
\hline
\end{tabular}




\title{
The economic consequences of IFRS: The impact of IAS 32 on preference shares in the Netherlands
}

\author{
Abe de Jong, Miguel Rosellón, Patrick Verwijmeren* \\ RSM Erasmus University, Rotterdam, the Netherlands
}

* $\quad$ Corresponding author. Tel: +31 10408 1276; fax: +31 104089017

E-mail address: pverwijmeren@rsm.nl. We are grateful for comments received from two anonymous referees, Doug DeJong, Gerard Mertens, Erik Roelofsen, Peter Roosenboom, Willem Schramade, Leo van der Tas, Marno Verbeek and seminar participants at RSM Erasmus University. 


\title{
The economic consequences of IFRS: \\ The impact of IAS 32 on preference shares in the Netherlands
}

\begin{abstract}
The consequences of international accounting standards are likely to reach beyond the impact on financial statements. This paper demonstrates one of the economic implications of international standards. We focus on the impact of the IFRS regulation on preference shares (IAS 32) in the Netherlands. IAS 32 causes most preference shares to lose their classification as equity and these shares will hence be classified as liabilities. We document that for Dutch firms with preferred stock outstanding, the reclassification will on average increase the reported debt ratio by $35 \%$. We find that $71 \%$ of the firms that are affected by IAS 32 buy back their preference shares or alter the specifications of the preference shares in such a way that the classification as equity can be maintained. The main determinant of the decision whether to give these consequences to IAS 32 is the magnitude of the impact of IAS 32 on a firm's debt ratio. We conclude that IFRS does not only lead to a decrease in the use of financial instruments that otherwise would have added to the capital structure diversity, but also changes firms’ real capital structure.
\end{abstract}

JEL classification: G32, G38, M41

Keywords: Economic consequences, accounting changes, IFRS, IAS 32, preference shares, magnitude effect 


\section{Introduction}

In the process of the worldwide harmonization of accounting standards, the European Commission has made reporting according to International Financial Reporting Standards (IFRS) compulsory for firms that are listed on a European exchange. Although IFRS is primarily meant to increase the transparency and comparability of European firms' financial reports, it will also reduce the gap between US standards and most national accounting standards in Europe. As the first annual reports with a compulsory compliance with IFRS will appear in 2006, we expect a considerable amount of research dealing with the impact of IFRS on the accounting figures in the reports. However, the consequences of IFRS are likely to reach beyond the impact on financial statements. The reason is that harmonized reporting standards are more probable than national standards to be misaligned with the underlying environmental conditions facing the firm and its managers, like taxation, regulation and managerial accounting figures (Choi and Levich, 1991). It is this inconsistency of international standards with national environments that leads Tang (1994) to conclude that the introduction of international standards can have serious economic consequences, because companies will adjust their behavior to fit the new accounting standards. This paper documents the decrease in the use of preference shares in the Netherlands as an important economic consequence of IFRS. We will provide evidence that the harmonization of accounting standards can lower the use of relatively unique instruments.

The focus of this paper is on the actions of a firm's management. So far, in the empirical economic consequences literature the focus has been on security price reactions to accounting changes (Watts and Zimmerman, 1990: 138). The reason that the reactions of firms' management to mandatory accounting changes have not been documented extensively is that management actions are limitedly observable. The reactions of managers are however more interesting, because they provide direct evidence of the economic consequences of accounting standards. As preference shares changes are relatively easy to detect, the IFRS standard on preference shares (IAS 32) provides an excellent opportunity to document managers' reactions to accounting changes. 
The IFRS regulation for preference shares has a considerable impact on Dutch firms' reported debt ratios, in comparison with the Dutch GAAP standards. For some firms, the debt ratio will be as much as doubled due to IAS 32. Furthermore, the new regulation can reduce reported net earnings, as the dividends on preference shares that are classified as a liability will appear on the profit and loss statement in the same way as interest payments do. These impacts are not cash flow related: as the tax treatment of the dividends resulting from the preference shares under Dutch GAAP is equal to the tax treatments of the dividends resulting from the classification as debt, there are no direct cash flow effects. The new accounting rules on preferred stock also seem relevant for the UK, as the UK and the Netherlands account for more than $90 \%$ of the value of preferred stock outstanding in Europe. However, in the UK most preferred stock remains classified as equity even with IFRS. Our country of interest is thus the Netherlands, allowing for a unique experiment on the economic consequences of accounting standards.

We find that $71 \%$ of the listed Dutch firms that are affected by the new rules for preference shares will either buy back their preference shares or change the characteristics of the shares in such a way that the classification as equity can be maintained. These changes are not the result of an ongoing trend over the preceding years: over the last three years there was one firm per year that bought back preference shares and there were no firms that changed the characteristics in a way comparable to the changes made in $2005 .{ }^{1}$ We find that the magnitude of the effect of IAS 32 on firms' debt ratios is the main determinant of firms' decisions to alter their capital structure specifications: for firms that make rigorous changes the difference between the debt ratio under Dutch GAAP and IFRS is 46.5\%; for firms that do not rigorously change the specifications of their capital structure this percentage is $19.1 \%$. We do not find evidence that the magnitudes of the impact of IAS 32 on firms' net earnings are a determinant of firms’ buyback decisions. As IAS 32 has no direct effect on cash flows, we hypothesize that the importance of the magnitude of the effect on the debt ratio can be explained by contracting-costs arguments. We find evidence that these contracting costs are mainly

\footnotetext{
${ }^{1}$ We do not count a decrease in outstanding preferred as a buyback in case it is the result of convertible preferred stock being converted.
} 
related to a firm's debt contracts. We do not find evidence that the contracts that a firm has with the government or its managers are capable of explaining firms' decisions to buy back preferred shares or to alter the specifications of these shares. However, our findings regarding contracting-costs hypotheses have to be interpreted cautiously, as these hypotheses are normally tested with larger data samples.

The remainder of this paper is organized as follows. Section 2 outlines the economic consequences of accounting standards. In section 3 the data is described. The results of this study are included in section 4. Finally, the conclusions are presented in section 5 .

\section{Economic consequences of accounting standards}

Zeff (1978, p. 56) defines economic consequences as "the impact of accounting reports on the decision-making behavior of business, government, unions, investors and creditors.” The essence of the definition is that accounting reports can affect the real decisions made by managers and others, rather than simply reflecting the results of these decisions. Sometimes an accounting standard is meant to have economic consequences. In most cases, however, the economic implications are unintended. Incentives for firms' managers to change their decision-making behavior on the basis of new accounting standards would not exist in a perfect world, as new accounting standards will normally not have direct cash flow effects and the prospects of firms remain unaltered. However, in the real world firms face contracting costs resulting from the contracts that firms have with various stakeholders, like transaction costs, agency costs, information costs, renegotiation costs and bankruptcy costs. The height of the contracting costs that a firm faces as a result of an accounting change depends on the magnitude of the effect of the accounting change. Studies that document the importance of this magnitude effect include Collins et al. (1981) and Ali and Kumar (1994). In our study we have two magnitude effects: the effect of IFRS on a firm's debt ratio and the effect of IFRS on a firm's net earnings.

Beginning with Watts and Zimmerman (1978), several studies have investigated the relationship between accounting changes and firm characteristics. There are three 
specific theories concerning firm characteristics that are most often used to explain the decisions of managers to give economic consequences to accounting changes (Watts and Zimmerman, 1990). These three theories deal with contracting costs that are the result of the contracts that firms have with their managers, the government and their debt holders. The theories can be tested with the bonus plan hypothesis, the political cost hypothesis and the debt covenant hypothesis. The bonus plan hypothesis states that managers with bonus plans are more likely to react to accounting developments, in order to increase their compensation. Both Healy (1985) and Guidry et al. (1999) find evidence in favor of this hypothesis. The second hypothesis is the political cost hypothesis. This hypothesis predicts that large firms rather than small firms are more likely to use accounting changes to reduce reported profits, in order to avoid laws and potential regulation. The threat of potential regulation stems, for example, from the fact that high profits could hint at a monopoly position. Although most evidence is consistent with the political cost hypothesis, the results only appear to hold for the largest firms (Zmijewski and Hagerman, 1981) and are driven by the oil and gas industry (Zimmerman, 1983). The bonus plan hypothesis and the political costs hypothesis both refer to contracting costs that are mostly relating to the effect of IFRS on net earnings. The debt covenant hypothesis, on the other hand, focuses on the change in debt ratio. This hypothesis states that managers select or change accounting methods to avoid covenant violations. The tightness of the accounting-based debt covenants is in most studies researched by looking at debt ratios (where higher debt ratios are associated with covenant tightness). This proxy is however not beyond questioning. Still, both Duke and Hunt (1990) and Press and Weintrop (1990) provide empirical support for the proxy's use, although Duke and Hunt argue that the debt ratio is not a good proxy for covenants dealing exclusively with debt/equity restrictions. Bank debt is a variable that is also likely to be related to debt covenants, as bank debt is the kind of debt that is normally specified in the contracts. Another way of testing the debt covenant hypothesis is by looking at firms that have actually violated their debt covenant. Sweeney (1994) examines a sample of firms that defaulted by violating debt covenants together with a matched firm control sample. She reports that the defaulting firms made more accounting changes in the period leading up to default and that a higher percentage of these changes were income increasing compared to the control group. 
The empirical economic consequences literature on mandated accounting changes has focused on security price reactions. There are however some exceptions, dealing with the impact of specific US standards on the reactions of firms' managers. Imhoff and Thomas (1988), for example, study the effect on the decision-making of managers of SFAS 13, which concerns capital lease disclosures. Another example is the research of Mittelstaedt et al. (1995), who investigate the impact of SFAS 106 (concerning postretirement benefits) on retiree health care benefit reductions. More recently, Carter and Lynch (2001) research the consequences of the FASB's 1998 proposal on accounting for stock option repricing. All three studies find that managers respond to the accounting changes by mitigating the standards' effects. However, in establishing the determinants of managers' reactions, none of the papers test more than one of the hypotheses described before. In this paper we follow a more integrated approach and test all of the hypotheses.

We document the impact of the IFRS regulation on preferred stock in the Netherlands. Preferred stock is a financial instrument that has been used by many Dutch companies. This stems from the fact that it is an instrument with various advantages. For example, for companies facing financial distress preference shares provide the possibility to postpone dividend payments. Other advantages of preference shares can be achieved by strategically using the shares' voting rights. For investors, preferred stock is an instrument that provides relatively predictable dividend payments and provides preferences upon liquidation (for which the investors may pay a premium). Also, in the Netherlands investors are sometimes willing to pay a premium as preferred stock may provide taxation benefits. These taxation benefits are the result of the Dutch 'deelnemingsvrijstelling', which is applicable to firms that possess more than 5 percent of the nominal paid-up capital of another firm. For the firms with this relatively large stake, the dividends and capital gains that flow from the other firm are tax exempt under the Dutch fiscal law, and this will remain so under IFRS. Although the 5 percent of the nominal paid-up capital can be obtained by buying common stock as well as preferred stock, common shares usually trade for a much higher amount than the nominal value, whereas preference shares do not. Buying preference shares is thus a relatively cheap way for firms to qualify for the tax exemption, making them willing to pay a premium. It is this environmental condition that is particularly likely to have stimulated the use of preference shares in the Netherlands. 
Our decision to focus on the Netherlands does not seem obvious at first, as we conclude after studying the Worldscope variable 'preferred stock'. With this Worldscope variable we trace companies with outstanding preference shares in 2004 and find that 434 European firms have preference shares outstanding, divided over 10 countries. $^{2}$ From these 434 firms, the majority (354 firms or $81.6 \%$ ) is UK-based. This popularity of preferred stock in the UK goes back to the first half of the $20^{\text {th }}$ century, when utilities issued them, just as their US counterparts were doing (Laurent, 2002). Later on, in the 1960s, the industrial firms followed as preference shares became popular in the merger wave, and the UK has been the country with the largest number of preference shares in Europe ever since. However, in the UK most preferred stock remains classified as equity even with IFRS. This is because most UK-firms possess the discretion of determining the dividend, which is an important prerequisite of IFRS for preference shares to be classified as equity. The second-most important European country for preference shares is the Netherlands, which accounts for $10.4 \%$ of European firms with preferred stock outstanding. In the Netherlands firms normally do not possess the discretion of determining the dividend. Consequently, Dutch firms are expected to face the strongest effect from the IAS standard on preferred stock. As no other country accounts for more than $3 \%$ of the total number of preference shares outstanding, we decided to solely focus on the Netherlands. ${ }^{3}$

Interestingly, our analysis of the Worldscope data does not find Germany to be among the countries in which preference shares are frequently used. This contradicts the common belief that preference shares are widely present in Germany. However, Becht and Boehmer (1999) report that the German preference shares do not contain voting rights, making them more similar to straight debt. Apparently, Worldscope does not

\footnotetext{
${ }^{2}$ Worldscope classifies priority shares also as 'preferred stock'. This results in an overestimation of the number of firms with preference shares (with voting rights).

${ }^{3}$ When we divide the number of preference shares outstanding in a particular country by the total number of preference shares outstanding in Europe we find the following percentages: UK 81.6\%, The Netherlands $10.4 \%$, Ireland 3.0\%, Germany 1.8\%, Hungary $0.9 \%$, Austria $0.5 \%$, Czech Republic $0.5 \%$, France $0.5 \%$, Spain $0.5 \%$ and Russia $0.5 \%$.
} 
classify these debt-like instruments as preference shares. This is also valid for non-voting preference shares in other European countries, like the action de préférence in France (Conac, 2005).

Under IAS 32 the popularity of preference shares may decline in the Netherlands. The reason is that IFRS poses different conditions on an instrument to be classified as equity than Dutch GAAP does. Under both accounting standards, an important condition for an instrument to classify as equity is that the instrument includes no contractual obligation to deliver cash or another financial asset to a different entity. In case an enterprise has preference shares that pay a fixed rate of dividend and have a mandatory redemption feature at a future date, the substance is that they are a contractual obligation to deliver cash and, therefore, should be recognized as a liability. Although most preference shares in the Netherlands do not have a contractual obligation to pay dividend, they do have a conditional obligation to pay dividend when the firm earns a profit. IAS 32 and Dutch GAAP differ in the way they treat the conditional obligation. Under Dutch GAAP the preference shares were classified as equity, because the substance of these instruments is that they share in the firm's results. IAS 32, however, states that an instrument should be classified as a liability if the issuer of an instrument does not have the unconditional right to avoid delivering cash or another financial asset. Hence, under IAS 32 most preference shares in the Netherlands are classified as a liability. ${ }^{4}$

Firms can respond to the impact of IAS 32 in several ways. These responses include options to change the real capital structure of the firm (as opposed to the reported capital structure), but also contains an option concerning the contracts a firm has with its debt holders. We will research the following potential responses of firms: (A) renegotiating the parameters of the debt contracts affected by the reclassification of preference shares; (B) mitigating the financial statement impact by changing the characteristics of the preference shares in such a way that the classification as equity can

\footnotetext{
${ }^{4}$ As stated before, the reason that in the UK most preference shares maintain their classification as equity is that most firms possess the discretion of determining the dividend on preference shares, and are thus not obliged to pay a dividend when the firm earns a profit.
} 
be maintained ${ }^{5}$; (C) mitigating the financial statement impact by buying back the preference shares; or (D) doing nothing.

We must be careful not to attribute a choice of option C automatically to the introduction of IFRS. Even though the date that IFRS became effective in the Netherlands, being the $1^{\text {st }}$ of January 2005, seems to greatly influence the use of preference shares, there is another development that has been going on for a couple of years. This development is the Dutch Corporate Governance Code ('Code Tabaksblat'), which was presented by the end of 2003 and is a code of conduct for listed firms. A significant part of the Code Tabaksblat deals with the rights of (common) shareholders. For outstanding preference shares, the most important paragraph of the code is paragraph IV.1.2, which states that the voting rights of preferred stock should be in line with the real value of the stock. The Corporate Governance Code does however not seem to be the main driver of the buyback of the preference shares in 2005, as it was already active in 2004. More importantly, the code does not require a firm to buy back its preference shares, but only to align its voting rights with the real value of the shares. Furthermore, firms are not obliged to act according to the code, as long as they explain the structure of the voting rights in their annual report.

\section{Data}

Our dataset consists of all 34 Dutch firms that are listed at the Euronext Amsterdam exchange and have preferred stock outstanding at the $1^{\text {st }}$ of January 2004 . We decided to include the financial institutions (5), because one of these firms bought back its preference shares and mentioned IFRS as the reason. Financial institutions can also provide information on our research on compensation schemes. The part of our research that relates to debt ratios is conducted with exclusion of the financial institutions, as financial institutions have risk-based capital ratios that are hard to compare with non-

\footnotetext{
${ }^{5}$ Firms do this by adding the discretion of determining the dividend when the firm makes a profit. In order to change these characteristics, firms need the permission of the holders of the preference shares.
} 
financial firms' debt ratio and that are also not affected by IAS 32. Other than in the financial sector, we did not find preference shares in more than three firms from a single industry, which excludes possible large industry-effects. ${ }^{6}$

In order to research the responses of the 34 firms in our sample, we studied their press releases on Euronext.nl and researched the news in the Dutch financial daily 'het Financieele Dagblad.' We also downloaded their annual reports, interim reports and articles of association from their websites. Finally, we corresponded with their spokesmen by e-mail and telephone. Data about firms' assets, sales, dividends, earnings, debt and equity are taken from the annual reports of 2004. Most Dutch firms provide information about their remuneration policy in their annual report of 2004 or in specific remuneration reports. Data about performance targets of managers are taken out of these reports.

We calculated firms' net earnings under IFRS by subtracting the dividends paid on preference shares from the net earnings under Dutch GAAP. Firms' debt ratios for 2004 under Dutch GAAP are calculated by dividing companies' current and non-current liabilities by their equity, as reported in their 2004 annual reports. The debt ratio for 2004 under IFRS is computed by determining the book value of the outstanding preferred stock that classified as a liability under IFRS, and we changed firms' equity and liabilities accordingly. The book value of the outstanding preferred stock was determined by again researching news in 'het Financieele Dagblad', the 2004 annual reports, the interim reports of 2005 and press releases on Euronext.nl. The reclassification includes the additional paid-in capital ('agio') related to the preference shares. Three firms withdrew their preference shares just before 2005 (when the impact of IAS 32 on the firm's financial statement was highly likely to be known). For these firms, the debt ratio for 2004 under Dutch GAAP is computed as if they had not bought these shares back.

\footnotetext{
${ }^{6}$ We did however find that all three firms with preferred stock outstanding in the food industry make rigorous changes (options B and C), just as all three firms in the machinery industry. Unfortunately, the limited sample does not allow us to really research an industry imitation effect.
} 


\section{Empirical evidence}

In order to test the magnitude effects, the political cost hypothesis, the bonus plan hypothesis and the debt contract hypothesis, we collected information on firms' size, (change in) debt ratios and net earnings, and compensation schemes. The net earnings variable is not scaled as it is usually the absolute height of this variable that is relevant for the government (as large firms' reported net earnings are likely to appear in the news) and the managers' compensation schemes (as some of the managers have net earnings targets). As we stated in the introduction, one has to be careful putting to much emphasis on our testing of the three contracting-costs hypotheses, as these tests are normally conducted on larger samples. Our main contribution thus follows from establishing the magnitude effects; the tests of the three other hypotheses can be considered as additional tests. Table 1 shows the firm characteristics of our dataset.

\section{[Insert Table 1 here]}

The mean of the total assets and total net sales of the firms in our sample are 54.6 and 9.1 billion euro, respectively. The medians of the assets and sales of our firms are with 1.7 and 2.1 billion euro considerably lower than these means. This difference is mostly driven by the relatively large size of the 5 financial institutions in our sample: without these financial institutions the mean and median of total assets will be 3.6 and 1.6 billion euro, respectively (not reported). This remaining difference is largely the result of two large firms in our sample (Koninklijke Ahold N.V. and Unilever N.V.). The outstanding preferred stock has on average a book value of 158 million euro, and accounts for $18 \%$ of the total equity. The average debt ratios in 2004 with Dutch GAAP and IFRS are on average 2.08 and 2.90, respectively. The impact of the new rules for preference shares on these debt ratios is considerable: firms' debt ratios increase on average with 35\%. The influence of IAS 32 on the net earnings is less in percentage terms. Furthermore, our finding that firms' net earnings decrease on average with $11 \%$ is largely due to two outliers. The median is therefore more relevant, which shows that IAS 32 decreases firms' earnings with about $4 \%$. 
Table 1 further shows that three firms do not specify their managers' performance targets. Most other firms (25/31) use performance targets that are not influenced by IAS 32. These targets will generally be related to cash flows, but can also be linked with earnings per share. The reason that IAS 32 does not generally influence a firm's earnings per share is that for calculating the common shareholders' earnings per share the dividend payments on preference shares are already subtracted from the earnings under Dutch GAAP. This subtraction of the preference shares' dividend does however only happen when calculating the earnings per share, and not when calculating the net earnings. Performance targets that are influenced by IAS 32 are therefore in most cases related to the net earnings. Qualitative targets are non-financial goals. Examples are strategic goals or an increase in customer satisfaction. Notice that managers can have multiple performance targets.

The economic consequences of IAS 32 are determined by the responses of firms to the standard. We report these reactions in Table 2. One firm chose to buy back part of the outstanding preference shares (book value 50 million euro) and to change the characteristics of the remaining outstanding preference shares (book value 65 million euro). Considering the higher book value of the latter, we decided to categorize this firm under option B (changing characteristics).

\section{[Insert Table 2 here]}

We find that the preference shares of three firms remain classified as equity under IFRS as these firms have the discretion of determining the dividends. None of these three firms made any changes to their preference shares. Table 2 also shows that 52\% (16/31) of the firms is going to buy back their preference shares and 19\% (6/31) will make an amendment to the characteristics of the preference shares, which allows these shares to classify as equity. Financial institutions are overrepresented in the group that responds by doing nothing. The reason is that financial institutions have risk-based capital ratios, and hence experience a lower impact of IAS 32 on the relevant debt ratios than non-financial institutions.

The options to change the characteristics of preference shares or to buy back these shares (options B and C) alter the current capital structure specifications: option B will 
increase the dividend rate that investors require on the preference shares (as they face the risk of the firm deciding not to pay a dividend) and option $\mathrm{C}$ changes the real capital structure. We classify these responses as rigorous changes. Options A and D can be seen as a minor (or non-existent) response to IAS 32, and are classified as a non-rigorous response. To determine the characteristics of firms that alter the specifications of their capital structure, we split our sample. Table 3 shows the results.

[Insert Table 3 here]

It can be seen from table 3 that the net earnings of firms that rigorously change behavior decrease with $12 \%$ (median: $-3 \%$ ), against 13\% (median: $-5 \%$ ) for firms that do not rigorously change behavior. However, this magnitude of the impact of IAS 32 on firms' net earnings is not significant. Our finding that the absolute values of the net earnings of firms that do not rigorously change behavior are higher is largely due to two firms: one firm that does not change behavior makes a large profit, and one firm that does change behavior makes a considerable loss. This difference is therefore also not significant, leading us to conclude that the magnitude of the impact of IAS 32 on firms' earnings does not drive the decisions of the firms in our sample.

Consequently, we do not find evidence in favor of the political costs hypothesis or the bonus plan hypothesis, as these hypotheses are related to the magnitude effect of IAS 32 on a firm's net earnings. The political costs theory hypothesizes that particularly large firms choose accounting procedures that are income reducing, as they are subjected to greater government scrutiny. Table 3 shows that in our sample it are the larger companies (average net sales: 10.6 billion euro) that allow IAS 32 to reduce the earnings. However, this size effect is largely an industry effect, as most large financial institutions do not react rigorously to IAS 32. Without the financial institutions, the size differences are only marginal. Furthermore, the difference is not significant, leading us to the conclusion that political costs do not drive the buyback decisions of Dutch firms.

Table 3 also provides information on the bonus plan hypothesis. It can be seen that $21 \%(4 / 19)$ of the managers that buy back preference shares or change the characteristics of these shares have quantitative performance targets that are influenced by IAS 32. For managers that do not rigorously change behavior, this percentage is $11 \%$ 
(1/9). However, the impact of the quantitative performance targets on the decision of a firm whether to make rigorous changes is again not significant. We have thus provided evidence that neither the magnitude of the effect of IAS 32 on a firm's net earnings or any relating contracting costs with managers or the government is capable of explaining firm's decisions to change the characteristics of their capital structure.

The other effect of IAS 32 is on firms' debt ratios. The magnitude of this effect can be determined by looking at the changes of the debt ratios for firms with and without rigorous changes. Table 3 shows that for firms that make rigorous changes the debt ratio would have increased on average with $46.5 \%$, against $19.1 \%$ for firms that do not rigorously change the specifications of their capital structure. As this difference is significant at the $5 \%$ level, we conclude that the magnitude effect of IAS 32 on firms' debt ratio is an important determinant of firms' decisions whether to change the specifications of their capital structure.

In order to research whether the impact of the magnitude effect on debt ratios can be explained by the debt covenant hypothesis, we first look at the static debt ratios, which have traditionally been used to test the hypothesis. For firms that make rigorous changes, the average debt ratio would have been 2.17 under Dutch GAAP, against a debt ratio of 1.94 for firms that do not change their behavior rigorously. The difference, however, is not significant. Another test of the debt covenant hypothesis is conducted by looking at the amount of static bank debt. As the amount of bank debt is on average higher for firms that do not change their behavior (0.32 against 0.28 for firms that rigorously change behavior), the likelihood of an important effect of the debt covenants is further decreased. However, due to the flaws of static proxies, the influence of debt covenants can not completely be ruled out. This is because the importance of the dynamics of these proxies: an increase of the debt ratio is highly likely to tighten the debt covenant. Considering our finding that the change of the debt ratio is significant, this provides evidence that the tightness of the debt covenants might still be important in firms' decisions whether to rigorously change behavior.

We will further test the importance of firms' debt covenants by looking at the firms that actually bought back their preference shares. Concerning our finding about the importance of the change of the debt ratio we hypothesize that firms that buy back their preference shares would probably do this in a way that decreases their debt ratios. There 
are several ways in which the buyback can be accomplished. One of these methods is using cash. However, cash may not always be sufficiently available. Other options are issuing equity and issuing debt. Since issuing equity will lower the debt ratio, we expect that most firms will buy their preferred stock back by issuing equity. To see if this expectation is justified, we analyze the 15 firms that already bought back their shares. ${ }^{7}$ Our findings our mostly in line with our expectations: 9 firms finance their buyback by issuing equity, 4 firms use cash and 2 firms issue debt. The characteristics of the three groups are presented in Table 4.

[Insert Table 4 here]

The transition to IAS 32 increased the debt ratio for firms that issue equity with $63 \%$. For firms that use cash or debt, this increase is significantly lower: $17 \%$ and $13 \%$, respectively. This finding again stresses the importance of the impact on the debt ratio and the relating debt covenants. Moreover, table 4 shows that researching the buyback methods of firms does also provide some evidence on the importance of the static debt proxies, as the static debt ratio of 2004 under IFRS proves to be a significant determinant of firms' decisions to mitigate the effect of IAS 32. Firms that use cash to buy back their shares have on average more cash available (although not significant). Our finding that the net earnings of the equity issuing firms in our sample decrease on average with $18 \%$ percent is largely due to one outlier. Consequently, the magnitude of the impact of IAS 32 on firms' earnings is again not significant.

The preference of firms to issue equity is interesting, as issuing equity can be considered as a relatively expensive way of financing, following from e.g. transactions costs and agency costs. According to Myers (1984), firms therefore only issue equity as a last resort. Our finding that the decision of firms to issue equity can be the result of accounting standards, is hence highly remarkable. Apparently, firms incorporate

\footnotetext{
${ }^{7}$ The 14 firms that are categorized under option C plus the firm that bought back one part of its preference shares and changed the characteristics of the remaining part.
} 
accounting considerations to a relatively high extent in determining the optimal capital structure.

Another interesting choice is to buy the preference shares back with debt, as this choice will normally not decrease the debt ratio. The explanations provided by the two firms that issue debt are that preferred stock loses its greatest advantage over debt when it is not considered equity anymore. Both companies state that they can issue debt with a lower interest rate than the dividend on their preferred stock (the dividend rate of the preferred stock for the firms were 6.74\% and 8.0\% in 2004 while they both expect an interest rate of about $4.0 \%$ ) and stress that interest is tax deductible, whereas dividend is not.

\section{Conclusion}

This paper has researched the economic consequences of IFRS, focusing on Dutch firms' reactions to the new regulation for preference shares. We have provided evidence that the implication of IAS 32, whereby most preference shares in the Netherlands qualify as a liability, is that the majority of Dutch firms with preferred stock outstanding choose to alter the specifications of their capital structure. Firms do this either by buying back the shares (52\%), or by altering the specifications of the preference shares in such a way that the classification as equity can be maintained (19\%). Our main contribution is that the magnitude of the impact of IAS 32 on firms' debt ratios is a significant determinant of firms' reactions, while the effect of IAS 32 on firms' net earnings is not. Consequently, when running additional tests on contracting-costs hypotheses, we do not find evidence in favor of the bonus plan hypothesis and the political costs hypothesis, as these hypotheses mainly deal with the earnings effect. Overall, the importance of IAS 32 on firms' debt ratios cannot be explained by looking at static debt ratios as a proxy for the tightness of debt covenants. However, as the impact on the debt ratio interacts with the tightness of debt covenants, we consider our evidence to be consistent with debt covenants playing a role in the buyback decisions of firms. Still, our tests regarding the contracting costs hypotheses have to be interpreted cautiously, as a more extensive dataset is normally required to run these tests. 
As this study establishes the importance of the magnitude effect of an accounting standard on firms' debt ratios, it is likely that other standards with a considerable impact on either the reported debt or equity will also change firms' behavior. IFRS standards that have the potential to considerably change the amount of reported equity (and thus the debt ratio) are the standards on goodwill (IFRS 3) and pension plans (IAS 19). This makes the economic consequences of these standards a particularly interesting research topic.

The buyback of preference shares makes us to conclude that IFRS leads to a decrease in the use of financial instruments that otherwise would have added to the capital structure diversity. Under IFRS, most advantages of preferred stock that form the initial reason to issue the shares remain valid: for investors, preferred stock remains an instrument that provides relatively predictable dividend payments, gives preferences upon liquidation and provides possible taxation benefits (deelnemingsvrijstelling). This will still lead investors to pay a premium. Other advantages of preference shares to companies, such as the option to postpone dividend payments and to strategically use the shares' voting rights, also remain valid. With the buyback of the preference shares as a reaction to IFRS, these advantages of the shares to companies and investors are sacrificed.

Considering our finding that the withdrawal of preference shares is in most cases combined with the issuing of equity, we further conclude that IAS 32 causes a shift towards a more equity-based capital structure in the Netherlands. We herewith provide evidence that accounting regulations are a determinant of firms' real capital structure, even if these regulations have no direct cash flow effects. 


\section{References}

Ali, A. and Kumar, K.R. (1994), The magnitudes of financial statement effects and accounting choice: the case of the adoption of SFAS 87, Journal of Accounting and Economics, 18, pp. 89-114

Becht, M. and Boehmer, E. (1999), Transparency of ownership and control in Germany, working paper

Carter, M.E. and Lynch, L.J. (2003), The consequences of the FASB's 1998 proposal on accounting for stock option repricing, Journal of Accounting and Economics, 35, pp. 51-72

Choi, F.D.S. and Levich, R.M. (1991), The capital market effects of international accounting diversity (New York: New York Salomon Brothers Center for the Study of Financial Institutions)

Collins, D.W., Rozeff, M. and Dhaliwal, D. (1981), The economic determinants of the market reaction to proposed mandatory accounting changes in the oil and gas industry: a cross-sectional analysis, Journal of Accounting and Economics, 3, pp. $37-71$

Conac, P. (2005), The new French preferred shares: moving towards a more liberal approach, European Company and Financial Law Review, 2 (4), pp. 487-511

Duke, J. and Hunt, H. (1990), An empirical examination of debt covenant restrictions and accounting-related debt proxies, Journal of Accounting and Economics, 12, pp. 45-63

Guidry, F., Leone, A.J. and Rock, S. (1999), Earnings-based bonus plans and earnings management by business-unit managers, Journal of Accounting and Economics, 26, pp. 113-142

Healy, P.M. (1985), The effect of bonus schemes on accounting decisions, Journal of Accounting and Economics, 7, pp. 85-107

Imhoff, E.A. and Thomas, J.K. (1988), Economic consequences of accounting standards: the lease disclosure rule change, Journal of Accounting and Economics, 10, pp. 277-310 
Laurent, S. (2002), Securities that do the deal: the decision to issue preference shares by UK firms, working paper

Myers, S.C. (1984), The capital structure puzzle, The Journal of Finance, 39, pp. 575592

Mittelstaedt, H.F., Nichols, W.D. and Regier, P.R. (1995), SFAS No. 106 and benefit reductions in employer-sponsored retiree health plans, The Accounting Review, 70 (4), pp. 535-556

Press, E. and Weintrop, J. (1990), Accounting-based constraints in public and private debt agreements: their association with leverage and impact on accounting choice, Journal of Accounting and Economics, 12, pp. 65-95

Sweeney, A.P. (1994), Debt-covenant violations and managers' accounting responses, Journal of Accounting and Economics, 17, pp. 281-308

Tang, Q. (1994), Economic consequences of the international harmonization of accounting standards: theory and its Chinese application, The International Journal of Accounting, 29 (2), pp. 146-160

Watts, R.L. and Zimmerman, J.L. (1978), Towards a positive theory of the determination of accounting standards, The Accounting Review, 53 (1), pp. 112-134

Watts, R.L. and Zimmerman, J.L. (1990), Positive accounting theory: a ten year perspective, The Accounting Review, 65 (1), pp. 131-156

Zeff, S.A. (1978), The rise of economic consequences, The Journal of Accountancy, December, pp. 56-63

Zimmerman, J.L. (1983), Taxes and firm size, Journal of Accounting and Economics, 5, pp. 119-149

Zmijewski, M. and Hagerman, R. (1981), An income strategy approach to the positive theory of accounting standard setting/choice, Journal of Accounting and Economics, 3, pp. 129-149 


\section{Table 1: Firm characteristics of our dataset}

This table reports some characteristics of the firms in our dataset. The net earnings and debt ratios with IFRS only refer to the impact of the rules on the classification of preference shares; other influences of IFRS are not taken into account. Banks and insurance companies (5) are for some variables excluded from the dataset, as for example their debt ratios cannot be compared with those of non-financial institutions. For the performance targets that determine the variable (bonus) remuneration of a firms' management, there are 3 firms excluded. This is because these firms do not disclose specific information about their managers' performance targets. Bank debt is the amount of debt that is related to (subordinated) bank loans or loans from other credit institutions. The debt ratio change can be computed by dividing the difference between the debt ratio with IFRS and Dutch GAAP by the debt ratio with Dutch GAAP. The net earnings change can be computed by dividing the difference between the net earnings with IFRS and Dutch GAAP by the net earnings with Dutch GAAP. The figures for assets, net sales, preferred stock, dividends, equity and debt are for 2004 and with Dutch GAAP. The figures for assets, net sales, preferred stock, dividends and net earnings are in millions of euros.

\begin{tabular}{|c|c|c|c|c|c|}
\hline & Mean & Median & Minimum & Maximum & $\mathbf{N}$ \\
\hline Total assets & 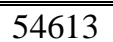 & 1735 & 40 & 866201 & 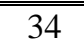 \\
\hline Total net sales & 9073 & 2059 & 96 & 82465 & 34 \\
\hline Preferred stock & 158 & 63 & 0.0 & 1502 & 34 \\
\hline Dividends on preferred stock & 8.7 & 3.9 & 0.0 & 44 & 34 \\
\hline Long-term debt/assets & 0.21 & 0.21 & 0.00 & 0.58 & 29 \\
\hline Short-term debt/assets & 0.38 & 0.38 & 0.13 & 0.75 & 29 \\
\hline Bank debt/assets & 0.29 & 0.27 & 0.02 & 0.77 & 29 \\
\hline Total debt/assets & 0.59 & 0.60 & 0.31 & 0.86 & 29 \\
\hline Total equity/assets & 0.35 & 0.34 & 0.12 & 0.69 & 29 \\
\hline Preferred stock/equity & 0.18 & 0.14 & 0.00 & 0.82 & 29 \\
\hline Dividend preferred stock/preferred stock & 0.09 & 0.06 & 0.00 & 0.68 & 34 \\
\hline Debt ratio 2004 Dutch GAAP & 2.08 & 1.82 & 0.39 & 6.89 & 29 \\
\hline Debt ratio 2004 IFRS & 2.90 & 2.30 & 0.39 & 10.42 & 29 \\
\hline Percentage change of debt ratio & 0.35 & 0.28 & 0.00 & 1.17 & 29 \\
\hline Net earnings 2004 Dutch GAAP & 436 & 57 & -436 & 5968 & 34 \\
\hline Net earnings 2004 IFRS & 427 & 42 & -480 & 5954 & 34 \\
\hline \multirow[t]{2}{*}{ Percentage change of net earnings } & -0.11 & -0.04 & -0.79 & 0 & 34 \\
\hline & & & & $\mathbf{N}$ & Total \\
\hline \multicolumn{4}{|c|}{ Firms with quantitative performance targets influenced by IAS 32} & 6 & 31 \\
\hline \multicolumn{4}{|c|}{ Firms with quantitative performance targets not influenced by IAS 32} & 25 & 31 \\
\hline \multicolumn{4}{|c|}{ Firms with qualitative performance targets } & 7 & 31 \\
\hline
\end{tabular}




\section{Table 2: Firms' reactions to IAS 32}

This table describes the distribution of the firms in our sample over response options A, B, C and D. One firm chose to buy back part of the outstanding preference shares (book value 50 million euro) and to change the characteristics of the remaining outstanding preference shares (book value 65 million euro). Considering the higher book value of the latter, we decided to categorize this firm under option B (changing characteristics).

\begin{tabular}{|llccc|}
\hline \hline & Finished & Going to & Total number \\
\hline A & Renegotiation of debt contract & 3 & 0 & 3 \\
B & Change the preference shares' characteristics & 3 & 3 & 6 \\
C & Buy back preference shares & 14 & 2 & 16 \\
D & 6 & 0 & 6 \\
& & & 31 \\
\cline { 2 - 4 } & Firms' preference shares that are affected by IAS 32 & & 34 \\
\cline { 2 - 4 } Firms' preference shares that remain classified as equity under IAS 32 & & 34 \\
\cline { 2 - 4 }
\end{tabular}




\section{Table 3: Differences of firm characteristics for firms that rigorously change their behavior and firms that do not rigorously change their behavior}

In this table we split our sample in firms that change the characteristics of their capital structure and firms that do not. The net earnings and debt ratios with IFRS only refer to the impact of the rules on the classification of preference shares; other influences of IFRS are not taken into account. Banks and insurance companies (5) are for some variables excluded from the dataset, as for example their debt ratios cannot be compared with those of non-financial institutions. The short-term remuneration policies of three firms could not be reported as these firms do not disclose specific information about their managers' performance targets. The three firms for which the preferred stock would remain classified as equity under IFRS are also excluded; notice that one of these firms is a financial institution. Bank debt is the amount of debt that is related to (subordinated) bank loans or loans from other credit institutions. The debt ratio change can be computed by dividing the difference between the debt ratio with Dutch GAAP and IFRS by the debt ratio with Dutch GAAP. The net earnings change can be computed by dividing the difference between the net earnings with IFRS and Dutch GAAP by the net earnings with Dutch GAAP. The figures for assets, net sales, equity, debt and dividends are for 2004 and with Dutch GAAP. Figures for assets, net sales and net earnings are in millions of euros. The t-test statistics are computed with equal variances assumed. Taking the t-statistics with equal variances not assumed will not change the range of significance of the variables. The range of significance of the compensations schemes are computed with the Pearson Chi-square statistic with continuity correction. *: sign. at $10 \%$ level, **: sign. at $5 \%$ level, ${ }^{* * *}$ : sign. at $1 \%$ level.

\begin{tabular}{|c|c|c|c|c|c|}
\hline & $\begin{array}{r}\text { Fi } \\
\text { rigo }\end{array}$ & $\begin{array}{l}\text { thout } \\
\text { hanges }\end{array}$ & Firn & $\begin{array}{l}\text { rigorous } \\
\text { ges }\end{array}$ & \\
\hline & $\mathbf{N}$ & Mean & $\mathbf{N}$ & Mean & $\begin{array}{c}\text { T-test } \\
\text { statistic }\end{array}$ \\
\hline Total assets & 9 & 99311 & 22 & 32304 & 0.91 \\
\hline Total net sales & 9 & 10606 & 22 & 8085 & 0.34 \\
\hline Long-term debt/assets & 7 & 0.24 & 20 & 0.19 & 1.03 \\
\hline Short-term debt/assets & 7 & 0.33 & 20 & 0.42 & -1.64 \\
\hline Bank debt/assets & 7 & 0.32 & 20 & 0.28 & 0.77 \\
\hline Total debt/assets & 7 & 0.56 & 20 & 0.61 & -0.93 \\
\hline Total equity/assets & 7 & 0.39 & 20 & 0.33 & 1.12 \\
\hline Preferred stock/equity & 7 & 0.10 & 20 & 0.24 & $-2.42 * *$ \\
\hline Dividends preferred stock/preferred stock & 9 & 0.05 & 22 & 0.11 & -1.06 \\
\hline Debt ratio 2004 Dutch GAAP & 7 & 1.94 & 20 & 2.17 & -0.43 \\
\hline Debt ratio 2004 IFRS & 7 & 2.47 & 20 & 3.21 & -0.89 \\
\hline Percentage change of debt ratio & 7 & 0.19 & 20 & 0.47 & $-2.37 * *$ \\
\hline Net earnings 2004 Dutch GAAP & 9 & 729 & 22 & 299 & 0.83 \\
\hline Net earnings 2004 IFRS & 9 & 724 & 22 & 288 & 0.84 \\
\hline Percentage change of net earnings & 9 & -0.13 & 22 & -0.12 & -0.15 \\
\hline & & 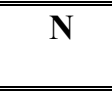 & & $\overline{\mathbf{N}}$ & $\begin{array}{c}\chi^{2}- \\
\text { statistic }\end{array}$ \\
\hline Quantitative and influenced by IAS 32 & 9 & 1 & 19 & 4 & 0.013 \\
\hline Quantitative and not influenced by IAS 32 & 9 & 8 & 19 & 16 & 0.000 \\
\hline Qualitative & 9 & 3 & 19 & 2 & 0.890 \\
\hline
\end{tabular}




\section{Table 4: Firm characteristics for three different methods to buy back preferred stock}

Characteristics of the three groups in which we divided the firms that buy back their preference shares, namely: by increasing equity, by increasing debt or by using cash. The net earnings and debt ratios with IFRS only refer to the impact of the rules on the classification of preference shares; other influences of IFRS are not taken into account. Although there are 9 firms that use equity, one of the firms is a bank. As banks have capital structures that cannot be easily compared with the ratios of non-financial firms, we calculated the debt and cash ratios by using the 8 non-financial firms. The debt ratio change can be computed by dividing the difference between the debt ratio with IFRS and with Dutch GAAP by the debt ratio of 2004 with Dutch GAAP. The net earnings change can be computed by dividing the difference between the net earnings with IFRS and Dutch GAAP by the net earnings with Dutch GAAP. The figures for assets are for 2004, with Dutch GAAP and in millions of euros. If a firm used a combination of methods (equity, cash and/or debt) to buy back preference shares, we categorize the firm under the buyback method that represented the highest value. The F-test statistics are computed with ANOVA. *: sign. at 10\% level, **: sign. at 5\% level, ***: sign. at $1 \%$ level.

\begin{tabular}{|c|c|c|c|c|c|c|c|}
\hline & \multicolumn{2}{|c|}{ Equity } & \multicolumn{2}{|c|}{ Cash } & \multicolumn{2}{|c|}{ Debt } & \multirow[b]{2}{*}{$\begin{array}{c}F \\
\text { (Anova) }\end{array}$} \\
\hline & $\mathbf{N}$ & mean & $\mathbf{N}$ & mean & $\mathbf{N}$ & mean & \\
\hline Assets & 9 & 8819 & 4 & 3601 & 2 & 1971 & 0.67 \\
\hline Debt ratio 2004 Dutch GAAP & 8 & 2.60 & 4 & 1.22 & 2 & 2.00 & 2.45 \\
\hline Debt ratio 2004 IFRS & 8 & 4.16 & 4 & 1.49 & 2 & 2.28 & $4.10 * *$ \\
\hline Percentage change of debt ratio & 8 & 0.63 & 4 & 0.17 & 2 & 0.13 & $3.38^{*}$ \\
\hline Net earnings 2004 Dutch GAAP & 9 & 188 & 4 & 160 & 2 & -42 & 0.15 \\
\hline Net earnings 2004 IFRS & 9 & 171 & 4 & 152 & 2 & -45 & 0.14 \\
\hline Percentage change of net earnings & 9 & -0.18 & 4 & -0.05 & 2 & -0.03 & 1.70 \\
\hline Cash/assets & 8 & 0.10 & 4 & 0.14 & 2 & 0.04 & 0.91 \\
\hline
\end{tabular}




\section{Publications in the Report Series Research ${ }^{*}$ in Management}

\section{ERIM Research Program: "Finance and Accounting"}

2006

Valuation Biases, Error Measures, and the Conglomerate Discount

Ingolf Dittmann and Ernst Maug

ERS-2006-011-F\&A

http://hdl.handle.net/1765/7592

The economic consequences of IFRS: The impact of IAS 32 on preference shares in the Netherlands Abe de Jong, Miguel Rosellón and Patrick Verwijmeren

ERS-2006-021-F\&A

\footnotetext{
A complete overview of the ERIM Report Series Research in Management: https://ep.eur.nl/handle/1765/1

ERIM Research Programs:

LIS Business Processes, Logistics and Information Systems

ORG Organizing for Performance

MKT Marketing

F\&A Finance and Accounting

STR Strategy and Entrepreneurship
} 